\title{
USING ON-LINE PLATFORMS TO OBSERVE AND MONITOR ELECTIONS \\ A Netnography of Mozambique
}

\section{Dércio Tsandzana}

Dércio Tsandzana is a PhD student of political science, Sciences Po Bordeaux, Pessac, and teaching fellow at Eduardo Mondlane University, Maputo

\begin{abstract}
This article aims to understand the political impact of social networking platforms on the general elections in Mozambique held on 15 October 2014. It focusses on how electoral observation and monitoring were carried out in Mozambique using online tools, and is based on an ongoing research project exploring young people in politics in Mozambique through the internet. It uses a qualitative approach of both interviews and digital ethnography to sketch the landscape of online electoral observation in Mozambique. The positions here are the result of abstraction and generalisation - the particular positions of individuals or groups will only ever approximate these generalised positions, which are reconstructed from the complexity of everyday situated experience. As a preliminary conclusion, we have noted that the internet allows the emergence of new perspectives in political participation in Mozambique, despite its limited access to the internet.
\end{abstract}

Keywords: political participation, electoral observation, social networks, Mozambique

\section{INTRODUCTION}

The emergence of the internet in recent years has been an important electoral tool for both voters and candidates. Websites have been relaunched, YouTube channels filled with videos, and Facebook, Twitter, or Instagram accounts created (or revived) in the hope that internet users will read, like, and share the election message of the day. More often than campaign strategists would like, however, the websphere has then produced an alternative selection of online campaign hits with unofficial videos, jokes, and memes going viral across social media timelines and walls. By the end of the campaign, a fair proportion of voters will have engaged with both official and unofficial information about the election on the internet. 
The internet has fast become a more popular means of communication than the traditional print and electronic media were until recently (Lee \& Verba 2012). The internet has also generated enormous interest about whether and how digital platforms, including social media, have any impact on politics. As a result, there is an increasing body of research evidence on the multiple relations between social media and politics from different perspectives (Calderaro 2018, p. 781). Similarly, Dahlberg $(2011$, p. 1) has noted that for well over a decade there has been widespread enthusiasm about the possibility of digital media advancing and enhancing democratic communication. This comes from a surprisingly diverse array of political interests, ranging from government officials to anti-government libertarians.

In addition, the growing use of digital technologies has intensified the production and circulation of digital data in Africa. A wide range of data are collected openly, often through digital surveys and, increasingly, discreetly via technologies such as mobile apps, text messages, satellite data, and smart captors. Far from simply following trends established in the West, the Global South - and Africa in particular - has become a place for experimenting with game-changing projects, from mobile money to the implementation of national biometric identification systems. Several scholars have already suggested that those practices constitute new forms of quantification, control and surveillance over people's lives.

Despite the premise that the internet opens 'political conversation' (StromerGalley 2003), we observe that the expansion of this debate is far from mechanical and unambiguous. It often appears rather limited, unequal and dependent on traditional media. For example, Farrell and Drezner (2004, p. 3) found that American political blogs generally draw only a fraction of the online audience that traditional media enjoys. According to Bimber and Flanagin (2005, p. 365), an array of actions in which technologies of information and communication are central has proven theoretically and empirically intriguing from the standpoint of collective action. Self-organising online groups, rapidly assembled networks of protesters, 'meet ups', new structures for interest groups, and 'viral' e-mail lists are all examples of collective behaviours employing advanced communication and information technologies.

Moreover, the internet has been used not only to disseminate information and debate public affairs, but has also been invested by civil society to renew forms of civic engagement. This is the current context in which Mozambique can be framed. A notable example is the emergence of online citizens' platforms such as Txeka, which started as a simple tool for social networking to express popular views on the country's political or social context. Its use was specifically reinforced during the general elections in October 2014 as one of the main tools 
for electoral mobilisation. According to Kemp (2019), internet access reaches only $18 \%$ of the population in Mozambique, mostly those living in urban areas. Despite this lack of access, there is a growing tendency to use information and communication technologies as a tool for political participation and engagement, especially by young people as the 'creators of a new popular culture' (De Boeck \& Honwana 2005).

However, during several demonstrations in which social networks were used as tools of social and political mobilisation in Africa (Honwana 2014), political actors attempted to control these spaces by shutting the internet and introducing taxes for mobile communication, as was the case in Tanzania and Uganda in 2018 and 2016 respectively. In 2018, for example, Algeria's government shut down the internet intermittently to prevent students from cheating in high school exams. Since May 2018 Chad's internet has been blocked by its government. According to these examples, Devermont (2019) argues that mobile phones and the internet cannot create a democracy out of an autocracy ${ }^{1}$. They can however facilitate the necessary first steps; much as the internet can be used to fuel democracy, it can also be used to disrupt it. Analysing internet shutdowns at election times in sub-Saharan Africa, Freyburg and Garbe (2018) have shown that understanding ownership of the internet infrastructure, in particular internet service providers (ISPs), is critical to understanding state internet control. This is because most direct forms of control require ISPs to comply with government requests. Using qualitative comparative analysis, the results of this study support a positive relationship between a temporary halt of internet provision and ISP majority ownership by authoritarian states when facing election-related violence.

\section{TXEKA}

This article aims to analyse the electoral observation process in Mozambique's 2014 general elections through the use of the digital platform called Txeka ('Watch it', in English). It started as a simple tool for social networking to express popular views on the country's political or social conditions and its use was specifically reinforced during the general elections in October 2014 as one of the main tools for electoral mobilisation. This platform was created by young activists in the run-up to the 2014 general elections and has operated by sharing localised information (maps and social network tools) on the elections.

The study will thus consider how digital platforms such as Txeka influenced electoral observation in Mozambique during the 2014 general elections. This is

1 Typically viewed as brutally repressive regimes where power lies in the hand of a single individual - it has been assumed that totalitarianism emerges in places where the rigours of extreme levels of individualism in capitalist societies draw people to a totalitarian ideology (Frantz, 2016). 
preceded by a theoretical discussion on the role of digital media in elections, followed by a review of prior research, including that of Mudhai (2013) and Dwyer (2019) on the impact of digital media.

Firstly, the study surveys political participation in the digital era in Africa. Secondly, the study considers theoretical perspectives on electoral observation and the internet in Africa. Thirdly, the study analyses the results regarding the Txeka experience as an on-line platform of electoral observation. Finally, the conclusion includes questions for future research.

\section{METHODOLOGY}

This study is based on the author's own practical experience, information collected on social media from Txeka's publications on its Facebook page, as well as in-depth interviews made between July and September in 2017 with the core team of Txeka. The Txeka team consisted of ten members of whom we spoke to five, including the platform's lead manager Tomás Queface. The remaining four were auxiliary members responsible for receiving, analysing and disseminating information received through the platform. These interviews were conducted using both faceto-face interviews, and via virtual communication (Skype video call) because some of these members were outside the country when the interviews took place. The selection of these correspondents was the result of a previous survey based on information obtained from Txeka's Facebook page and website, as well as through contacts shared on the online election platform that were publicly accessible.

The interview focussed on three essential questions: first, the motivations for creating Txeka; second, how the Txeka platform enabled political participation during the elections; and third, how Txeka measured the quality of the debate on internet social networks during the 2014 election period. The resulting answers were also obtained through 'netnography' or 'digital ethnography' (Hine 2000; Kaur-Gill \& Dutta 2017). Hine (2000) was one of the first to apply the ethnographic paradigm of the constructed nature of the field in anthropology reflexively within internet studies (Marcus 1998), systematising her 'principles for virtual ethnography' from a multisited and connective notion of ethnography. Hine approaches virtual ethnography through the participant observation of different web pages as well as their links with mass media. Markham (2006) argues that the internet has been understood methodically as both a field site and a research tool. The first concept highlights the way in which the internet and its different platforms and technologies have become the context of participant observation, that is the field site or the locus of the social interaction between the ethnographer and his or her respondents. The second puts the emphasis on the internet as a means for data collection. 
As initially noted, we hypothesise that the Tseka platform in Mozambique has served as a permanent mechanism to generate significant information on the electoral process. However, the increase in awareness does not necessarily imply any more civic engagement in the political debates at large in this specific case. Our analysis of Txeka's Facebook page was based on three assumptions:

- As a communicative medium, that is to communicate with the participants across time and distance;

- As a data source, including the participants' status updates, message contact and photos;

- As a context, with a shared, observable space that fed into and framed data collection.

For this purpose, we tracked keywords with the hashtags \#Txeka \#EleicoesMoz \#Mocambique2014 \#Mozambique2014. This led to five publications that were the subject of this article in the section in which we cover the Txeka's Facebook page as an electoral observation platform. The retrieval of the keywords was done through the research engine based on the 'filter per page' contained on Facebook itself. Then we chose the publications made known during the September and October 2014 electoral campaign and elections respectively. For this it was necessary to be a follower of the Txeka (like) page in order to follow each publication by activating the 'follow first' function. In addition, it was necessary to add each member of the Txeka team as a friend, which made our work easier.

\section{DEFINING DIGITAL MEDIA AND SOCIAL NETWORKS AND THEIR SITES}

There is no consensus in the literature about the concepts of digital media and social network(s) site(s). According to Schroeder (2018, p. 1), digital media have been responsible for some of the most wide-ranging changes in society over the past quarter century. At the same time, there is little agreement in the social sciences about how these changes should be understood. One reason is increasing disciplinary specialisation. For instance, media and communication studies concentrate on specific areas such as the news or influencers on social media, without a broader analysis of what people do online. Political science has tended to concentrate on specific questions, such as the role of media in election campaigns or for social movements.

According to Castells (2001, p. 9), 'a network is a set of interconnected links - modes of organization with extraordinary benefits, because they are naturally flexible and adaptable, essential qualities for surviving and thriving in a changing environment'. More broadly, a social network can be a social structure of the 
internet, where elements are constituted by organisations or individuals, and whose links represent established interactions such as political, corporate, service, family, and friends. The main function of each network is mass communication and the transmission of knowledge, which will be examined in more detail. Authors such as Matos (2009) show that social networks can consist of a set of both physical and non-material spaces in which social agents can effectively participate in the process of public communication. Pereira (2011, p. 16) explains that the potential of the internet is:

reaching individuals who, at first, without any political ties to the classical institutions of civil society, are willing, as long as they are 'properly' convinced, to participate in specific protest actions, cybernetic or not, that have some identity with their interests and perceptions of the world.

Boyd \& Ellison (2008, p. 210) define social network sites 'as web-based services that allow individuals to (1) construct a public or semi-public profile within a bounded system, (2) articulate a list of other users with whom they share a connection, and (3) view and traverse their list of connections and those made by others within the system'. The nature and nomenclature of these connections may vary from site to site. For example, while we use the term 'social network site' to describe this phenomenon, the term 'social networking sites' also appears in public discourse, and the two terms are often used interchangeably. 'Networking' emphasises relationship initiation, often between strangers. While networking is possible on these sites, it is not their primary objective, nor is it what differentiates them from other forms of computer-mediated communication (CMC). For the purposes of this article, we will consider Facebook as a site which helps strangers to connect with each other on the basis of mutual interests, political views, or activities. Boyd (2008, p. 211) further claims that 'what makes social network sites unique is not that they allow individuals to meet strangers, but rather that they enable users to articulate and make visible their social networks'.

\section{POLITICAL PARTICIPATION IN THE DIGITAL ERA IN AFRICA}

According to Dimitrova (2011, p. 100), the impact of digital media on voters may differ depending on the type of digital media under examination; that is different forms of digital media, which carry different primary functions, may lead to different effects on voters. Indeed, consulting political news websites may be qualitatively different from blogging, connecting with a politician or like-minded others on a social networking site. As digital media evolved, the sites of political 
candidates and political parties have become more interactive and have begun to incorporate more multimedia and interactive features (Foot \& Schneider, 2006). Newer digital media forms, including blogs, online video sites such as YouTube, and social networks such as Facebook, provide even more opportunities for connecting politicians and voters.

Brossier (2013) asserts that the implementation of participative practices in democracy has taken place in Africa since the 1990s. Donors (international financial institutions and NGOs) have provided aid programmes with political conditions to ensure that states engage in prescribed reforms, particularly in decentralisation processes that aim to liberalise African economies. Because political participation goes beyond the vote as the only modality to allow this type of participation, young people find new mechanisms of interpellation in social networks with the increased use of the internet, especially in cities. Africa's urban environment is characterised by demonstrations, mainly by politically active but economically marginalised young people.

This vision of political participation echoes what Muxel (2016, p. 38) calls 'new uses of politics' - the rise and spread of political abstention reflects a profound change in the civic norm and the citizenship model. However, even though the most recent municipal elections in Mozambique in 2018 had a turnout of more than $60 \%$, participation has gradually given way to institutional mistrust, civic fatigue, democratic disenchantment or even negative politicisation (ibid.).

Regarding digital media in Africa, Huet (2017) shows that the continent is breaking new ground with new uses and is completely revolutionising everyday solutions. Huet further identifies five elements that have allowed Africa to skip development stages vis-à-vis other continents: telecommunications, mobile financial services, e-commerce, e-government and the economy of collaborative platforms. From Egypt to South Africa, Nigeria to Ethiopia, popular protest is emerging as a new force for political change across Africa. Widespread urban uprisings by youth, the unemployed, trade unions, activists, writers, artists, and religious groups are challenging injustice and inequality.

Nyabuga \& Mudhai (2009) cited by Mare (2015), investigated the use of new media technologies by mainstream political parties in Kenya during the disputed 2007 election. They argue that new media has the potential to strengthen the process of monitoring elections as well as to mobilise political activities and possibly encourage political engagement. However, it can also reinforce the positions of those in power and as such is susceptible to manipulation by human agents.

According to Devermont (2019), mobile phones have played a powerful role in this regard. He notes that in 2008 sub-Saharan Africa had about 800 protests - in 2018 there were just under 4000 protests - and part of that escalation can be 
chalked up to more phones and internet users 'lowering the barriers to organizing'. Drawing on interviews and in-depth analysis, Branch and Mampilly (2015) offer an insightful assessment of contemporary African protests, situating the current popular activism within its historical and regional contexts. For example, Bruijn (2019) notes that the changes brought by the internet are met with huge optimism for Africa and source of glory and revolution. But in practice there is another aspect, and academic publications increasingly indicate that Africa is facing a new form of digital divide in which the continent is (again) on the margins.

\section{THE INTERNET, ELECTION MONITORING AND OBSERVATION IN AFRICA}

The terms observation and monitoring are frequently used interchangeably as synonyms during elections, but they differ. According to the Guidelines for African Union Electoral Observations and Monitoring Missions (AUEOM 2002), observation involves gathering information and making an informed judgement, whereas monitoring involves the authority to observe an election process and to intervene in that process if relevant laws or standard procedures are being violated or ignored. However, electoral observation is not limited to election day only and has three moments of observation: before, during and after election day (Adebisi et al. 2013).

Electoral observation and monitoring have become an integral part of democratic and electoral processes in Africa. International, regional and national observers play important roles in enhancing the transparency and credibility of elections and democratic governance in Africa and the acceptance of election results throughout the continent. Referring to Zambia, Gwagwa (2016, p. 5) remarks that

... Zambians are using platforms such as WhatsApp for activism. They set up private groups where they can discuss issues with some measure of anonymity as there is no name against a post. There are a number of online projects taking shape or emerging, such as, the OSISA Situation Room, iFace situation room at provincial level and Zambia Election Information Centre, launched on 19 May 2016 to facilitate citizens' engagement in real-time using smartphones.

In the last three decades, the presence of both domestic and international election observers has become a point of continuity in elections in many African countries. As a result, researchers have been investigating the efficacy and impact of electoral observation in Africa since the 1990s. Several key themes include: 
- how effective observers are at detecting electoral fraud

- whether they are biased

- which standards they use to judge elections

- how they are perceived in host countries

- whether their presence leads to unintended consequences.

In evaluating the role of international observation of Kenya's 2017 elections, Molony and Macdonald (2019) have shown that specific allegations of incompetence and bias fail to acknowledge how international observers' preliminary statements refrained from offering final verdicts or commenting on the tallying process from which the problems emerged. Rather, due to a combination of media environment and popular expectations about observers' work, the complexity of their statements was lost as their findings were disseminated. This suggests that a fairer critique of international observers would focus on how they communicate, including when they decide to make their statements.

In Mozambique legislation allows local organisations such as political parties, associations, NGOs and citizens to observe elections. The 2018 legislation defines electoral observation as 'the conscious, genuine, responsible, appropriate and impartial verification of the various stages that the acts comprise'. This process covers all phases of the electoral process, from its inception to the validation and proclamation of election results by the Constitutional Council. Prior to the emergence and massification of new tools and platforms of communication and information provided by the internet, the observation process had been in place since Mozambique's inaugural elections in 1994. This included both local organisations and international observation missions, among them the SADC Electoral Observation Mission, European Union Election Observation Mission and African Union Election Observation Mission.

The first multiparty elections in Mozambique, held in 1994 in the aftermath of its civil war, show how essential national validation is to convince citizens that domestic institutions are reliable. At that time there was substantial international support to avoid a conflict like that in Angola in 1992 (Leeffers 2017, p. 4). The incumbent party won the elections which were generally regarded as free and fair; the main opposition (rebel) group did not reject the results although it had threatened a boycott in the case of an unfavourable outcome. However, without observers there would probably have been a different outcome (Lyons 2004).

Electoral observation is open to foreign observers and journalists, but there is no mention of the use of the information and communication technologies as electoral monitoring tools. However, in the 2018 municipal elections the National Electoral Commission (CNE) introduced new tools to consult electoral lists and results through internet platforms. Specifically, the CNE provided a website where 
voters could use their voter numbers to identify their polling stations, as well as the name on each polling station list. By October 15, another website was made available in which the results of each municipality's election were published. This website was however problematic as within hours of the release of the first results some failures were recorded, access was slow and in some municipalities the results were missing ${ }^{2}$.

The relation between electoral observation and monitoring and the internet in Africa has been studied by many scholars in recent years (Dzisah 2008; Ifukor 2010; Mudhai 2013; Ndavula et al. 2014; Salgado 2016). Nyabola's (2018) groundbreaking work reframes democracy from an African perspective and opens up new ways of understanding our current global online era. This author explores the drastic efforts being made by elites to contain online activism, as well as how 'fake news', a failed digital vote-counting system and the incumbent US president's recruitment of Cambridge Analytica contributed to tensions around Donald Trump's election. From the upheavals of recent national elections to the success of the \#MyDressMyChoice feminist movement, digital platforms have already had a dramatic impact on political life in Kenya, one of the most electronically advanced countries in Africa. While the impact of the Digital Age on Western politics has been extensively debated, there is still little appreciation of how it has been felt in developing countries such as Kenya, where Twitter, Facebook, WhatsApp and other online platforms are increasingly a part of everyday life.

According to Dodsworth and Cheeseman (2019), the elections increasingly involve technology at various stages of the electoral cycle. This ranges from biometric voter registration in advance of the election, to biometric identification on election day, e-voting, digital vote tallying and the electronic transmission of results. These new technologies create a number of challenges, both for the election and monitoring observation missions deployed by international organisations, as well as for the civil society groups that operate as domestic observers or election watchdogs'. The uptake of new electoral technologies varies between countries and between different parts of the election process. Many African countries have been early adopters of biometric voter registration and some have taken steps towards introducing electronic voting machines. According to ABC News, in 2014 Namibia became the first African nation to use electronic voting machines (EVMs) which were provided by Bharat Electronics Limited, an Indian state-owned company. Recently, Kenya (2017), RDC (2018), and Nigeria (2019) have experienced challenges in using technology for elections, both for registration and voting.

2 O website deixou de estar disponível para acesso público dias após a divulgação dos resultados de quase todos os municípios. 
In a 2019 study entitled Social media and politics in Africa: democracy, censorship and security, Dwyer drew on over a dozen new empirical case studies, from Kenya to Somalia, South Africa to Tanzania. She explored how rapidly growing social media use is reshaping political engagement in Africa. But while social media has often been hailed as a liberating tool, the book demonstrates how it has also served to reinforce existing power dynamics, rather than challenge them. For the author, the smartphone and social media have transformed Africa, allowing people across the continent to share ideas, organise and participate in the realm of politics like never before. While both activists and governments have turned to social media as a new form of political mobilisation, some African states have sought to clamp down on this technology by introducing restrictive laws or shutting down networks altogether.

Presidents Kagame of Rwanda and Kenyatta of Kenya are among a growing group of African politicians using social media to leverage their communications with citizens ${ }^{3}$. From Egypt to Zimbabwe, Zambia, Nigeria, Ghana, The Gambia and South Africa, as well in many other African countries, election candidates are increasingly taking to Twitter, Facebook, Snapchat, WhatsApp and other platforms to generate viral messages whose influence and scope are yet to be examined. It is important to consider the results and impact of spreadable or viral messages from traditional and social media on elections in Africa in relation to changing political, economic and social contexts.

The many issues involved include the cost of access for users, politics of ownership of the networks and the impact of viral media cultures on power relations in the democratisation process ${ }^{4}$ - what some scholars call 'the digital divide' (Dahlberg 2015; van Dijk, 2012). According to the Alliance for Affordable Internet (A4AI 2019), the biggest barrier for online access today is the cost of data. While people in high-income countries typically pay less than $1 \%$ of their average monthly income for 1GB data, the figure in Africa is $9 \%$. However, in the interests of connectivity and of overcoming the digital divide, Facebook has encouraged a number of ways for mobile phone users to use Facebook at little or no cost, including via cheap SIM cards and Facebook's '0' service, both of which enable users with basic mobile devices to connect to a text-based Facebook interface (Leistert 2013).

3 Paul Kagame (President of Rwanda) has more than 1400000 followers on Twitter. Uhuru Kenyatta (President of Kenya), is the most followed African leader on Twitter with 3.62 million followers. Media blackout in Kenya sparked speculation that his handle, @UKenyatta, may have been debarred by the microblogging site. The verified Twitter account was the first to be suspended. Search for UKenyatta returned a 'Sorry, that page doesn't exist!' response, and the President's Facebook account was suspended shortly thereafter.

4 Symposium organized by the Africa Media Centre, Communication and Media Research Institute (CAMRI). 


\section{TXEKA: USING AN ONLINE PLATFORM TO OBSERVE ELECTIONS IN MOZAMBIQUE}

Txeka was funded in 2014 by the Canada Fund for Local Initiatives (CFLI) 5 . The Canadian High Commission in Maputo partnered with non-governmental organisations (NGOs) in Mozambique and Kenyan to develop a Portugueselanguage web-based application that empowered ordinary citizens to use their smartphones to report on election irregularities in the lead-up to the election. One of the beneficiaries of the direct support of Canada's initiative was the Olho do Cidadão [Citizen's eye], a youth civic organisation that uses internet social networking as a platform for political participation based in Maputo. In the 2014 general elections, this organisation implemented the project Txeka, a platform based on the technology used in Kenya's 2010 elections as a result of violence recorded there. This platform allowed citizens to report problems regarding Mozambique's real-time elections through social media (Facebook), SMS, and mobile applications. Through mobile use, the Txeka platform encouraged participation and better accountability and transparency, enabling citizen engagement in the electoral process. On 15 October 2014, Mozambique's national election day, Txeka was made available for Android phones via Google Play and for Apple phones via iTunes. Users across Mozambique were able to download the app for free. Through this app, citizens sent reports and shared photos and videos with the Txeka team of ten analysts in Maputo who were trained by teams of Ushahidi ${ }^{6}$ specialists. Certified election observers also receiving training on how to use Txeka and were deployed across Mozambique. Ushahidi's Kenyan representatives were on hand on election day to help process incoming data.

During the lead-up to the election, the Txeka team in Maputo uploaded information they received on irregularities to a live online map of Mozambique on its Txeka website [https://txeka.co.mz/]. Citizens without smartphones (hence without the Txeka app) sent text messages directly to the Txeka team ${ }^{7}$. On election night a situation room was set up in Maputo by private television (STV) with participants from the National Election Commission, civil society organisations (CSOs), the main political parties, and the media. The Txeka map was a key

5 The CFLI is designed to support small-scale, high-impact projects in developing countries, which align with Global Affairs Canada's thematic priority areas for engagement. The programme is directed at projects conceived and designed predominantly by local partners. Projects are selected and approved by the relevant embassy or high commission of Canada.

6 The organisation uses the concept of crowdsourcing for social activism and public accountability, serving as an initial model for what has been coined as 'activist mapping' — the combination of social activism, citizen journalism and geospatial information.

7 According to Statista (the statistics portal) 67.92 people per 100 habitants subscribed to mobile cellular use in Mozambique in 2014. We consider these numbers as important to understand how the Mozambicans were connected using mobile phones. 
feature in providing real-time data that allowed stakeholders to discuss citizen concerns on the fairness and transparency of the electoral process. However, the observation process had a legal obstacle (Electoral Law No. 7, 22 February 2013, 22 ${ }^{\text {th }}$ February, amended by laws no 6 and 7, 3 August 2018). These indicate that the findings verified during the electoral process by observers must be submitted in Portuguese to the National Election Commission and to its support bodies, the Technical Secretariat of the Electoral Administration (STAE), District Electoral Commission (CDE), and Provincial Electoral Commission (CPE) according to each area of electoral observation. This is considered to be one of the main limitations to electoral observation problem-solving. These electoral problems must be resolved at the local level before being forwarded to the central bodies as CNE or STAE.

The Txeka team received more than 3000 messages from Mozambicans across the country, and was followed by 14000 Facebook users. Analysing two electoral moments (before and during elections), we noted that the Facebook page published many posts (see screenshots 1 to 8$)^{8}$ using the hashtag \#Txeka to promote online electoral observation and monitoring. However, access to the internet and therefore to social networks cannot be taken as universal, even with the availability of the 'free Facebook' service (known as free basic) which started in 2015. Mozambique has limited access to the internet (only 18\% in 2019), making for limitations of equal access on platforms that seek to promote virtual political participation such as Txeka. With a population of around 30 million, internet access is thus for only a minority in Mozambique.

According to Queface', Txeka's technical manager, outgoing messages were synchronised on a map allowing quick and easy identification of their senders. This exercise was made possible with the online map available on the platform. At each signal on the map, the members of the situation room - each equipped with a computer and mobile phone - were responsible for contacting the sender to verify the information before final sharing on social networks. This was especially for the preservation of information, the sender's security and the accuracy of the information. Strategically the team was divided between message receivers, verifiers and publishers. Txeka provided different mobile numbers to do the same work by the 'txekadores' ${ }^{10}$ who received the calls and answered each message. Also, Txeka's Facebook was categorised by two key messages which could be ranked in order of importance: electoral violence (during the campaign and on polling day) and dissemination of results on election night.

8 All screenshots were used with permission of the Txeka team with translations from Portuguese to English by the author.

9 Interview 20/07/2017, Maputo - Mozambique [by Skype]

10 Local expression to designate a member of Txeka's platform. 
While it was not possible to ascertain technically which regions reported the most messages that election day, Monteiro ${ }^{11}$ (a txekadora) established that the cities of Maputo and Nampula were more prominent. Our interviewee further stated that each message or call received that day came specifically from a focal point based at a voting station as an observer of CSOs such as the Youth Parliament of Mozambique. Regarding electoral observation and monitoring plan and strategy, Txeka's own Facebook page included a publication made on 10 October with appropriate guidelines, and an explanatory leaflet outlining steps to sending communication to Txeka headquarters (see screenshot 1 and image 1).

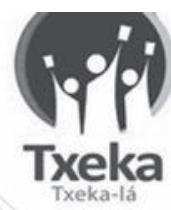

Txeka

@TxekaMoz

Accueil

Publications

Vidéos

Photos

À propos

Communauté

Infos et publicités

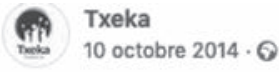

Txeka é uma Plataforma tecnológica que irá permitir os cidadãos observarem o processo eleitoral em Moçambique, podendo partilhar informaçőes a partir de SMS, Aplicativo Móvel, twitter e do Website.

Para partilhar informações sobre as eleições usando o SMS, envie o texto para os seguintes números: 842154520.829887685 ou 861392625 . É importante que menciones a lugar onde o evento decorreu ou está a decorrer.

Para partilhares informaçōes através da Aplicativo Móvel faça download do aplicativo TXEKA no Play Store ou APPStore e instale no teu dispositivo móvel.

Use no TWITTER uma das seguintes \#Hashtags sempre que fores a publicar alguma informação sobre as eleições: \#Txeka \#EleicoesMoz \#Mocambique2014 \#Mozambique2014 Assim você estrá interagindo com plataforma Txeka.

Você poderá também enviar um email para txekamoz@gmail.com ou acessar o site www.txeka.org.mz para submeter informações sobre as eleiçōes na plataforma Txeka.

Conte tudo o que está acontecer no teu bairro e comunidade sobre as eleiçōes. Sempre que partilhares informaçōes com o Txeka, não esqueça de dizer mencionar a localização. Todas as informações serão tratadas de forma anónima.

[Screenshot 1: To interact with Txeka, use the Twitter \#hashtags whenever you are posting information about the elections: \#Txeka \#EleicoesMoz, \#Mocambique2014 \#Mozambique2014. You can also email txekamoz@gmail.com or go to www.txeka.org. $m z$ to submit information about the elections on the Txeka platform. Tell us everything that is happening in your neighborhood and community about the elections. Whenever you share information with Txeka, do not forget to mention the location. All information will be treated anonymously I October 10, 2014] 


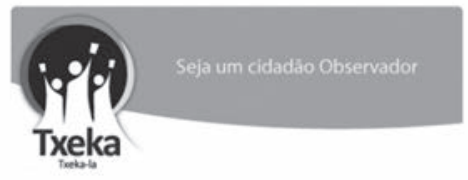

Informações Úteis para Observadores
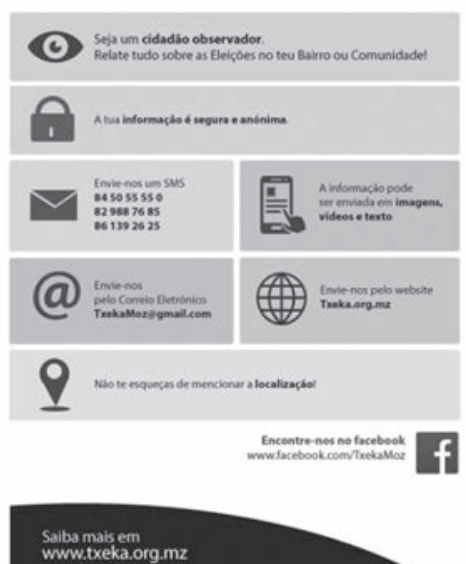

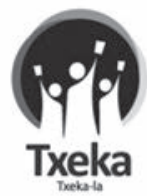

Txeka-la é uma plataforma web desenvolvida com a finalidade de monitorar as Eleiçóes Gerais e das Assebleias de Voto de 2014. Participe enviando-nos informaçóes sobre o processo eleitoral e estarás contribuir para eleiçóes transparentes.

\section{Diga-nos o que você vê e a localizaçào}

do evento!

tis

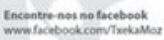
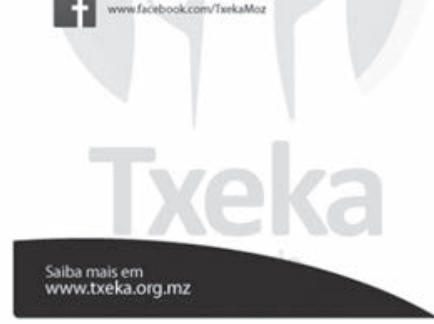

(1) Multipartyoumoocracy Canadä

[Image 1: Steps and instructions for observers to interact and send information - mobile numbers, voice, SMS, e-mail and website]

Our interview with Zandamela, a member of Txeka, explained in an interview in Maputo on 22 July 2017 that this was the first Mozambican platform for electoral monitoring created for young Mozambicans to show their views on politics:

I believe that every young person who uses a smartphone has at least Facebook and WhatsApp. There is a fringe of young people who don't use social network tools to share information about their own life, but they use some to manifest what they like or dislike about the Government in particular, and about politics in general. In 2014, there were few civil society organizations covering elections, but Txeka appeared as the first one. Today there are many online platforms that also want to do the same and we will have more online platforms doing the same process during next elections. 
On the other hand, Nhampossa (also member of the Txeka situation room team), explained in a Skype interview on 18 July that the electoral discussion between members of different political parties on the internet during the general election was radical and ideological. In particular, the debate on polarisation sought to defend political parties without openly discussing their candidates' ideas for those elections. This accords with several studies (Fisher, 2013; Nelimarkka, 2018; Beaufort, 2018) which analysed the polarisation of opinion created by internet social networks in other countries. Nhampossa also recalled that Txeka uploaded the main electoral manifestos of Frelimo, Renamo and the MDM together with electoral legislation to promote online debate during general elections. Though some Facebook pages appeared to discredit Txeka's work, Nhampossa noted that this was to be expected, because of the tension:

Each citizen's comments were motivated by their ideologies. However, we can highlight three groups: the first group which was seen as neutral, the second that identified as partisan, and last but not least the third group that only commented to disrupt the process. We cannot say so much about the debate on electoral manifestos, there was only debate about the behavior of the political parties or even about the candidates. What happened was that those who raised questions about the manifestos were only the academics.

(Nhampossa, Maputo 2018)

These interviews suggest that Txeka was an important channel of communication through which political communities or individual members of the public community provided information about their activities, publicised their positions on specific topics, shared information from multiple sources, and reported on issues surrounding them at a specific time (Calderaro 2018, p. 783). However, we noted that this process was not uniform because the debate was polarised, fragmented and made by specific actors - those members of political parties who were already engaged in politics. In other words, Txeka was a space to practice 'politics as usual' (Margolis \& Resnick, 2000), thus questioning the relevance of this platform.

The training of platform managers encountered several difficulties because they depended on external entities, mainly Ushahidi ${ }^{12}$ to use Txeka, and this was considered a barrier and organisational limit to guaranteeing the sustainability of their activities. There was no long-term sustainability or consistency of the

12 Ushahidi, testimony in Swahili, was developed to map reports of violence in Kenya after the postelection violence in 2008. The organisation uses the concept of crowdsourcing for social activism and public accountability, serving as an initial model for what has been coined 'activist mapping' - the combination of social activism, citizen journalism and geospatial information. 
initiative once the elections ended, as evidenced by the temporary closure of the Txeka website, the disintegration of the 2014 project team, and lack of continuity with the same criteria and strategy in the October 2018 elections. On the other hand, the availability of material and financial funds to initiate activities was conditioned by electoral observation and monitoring during the prior phases (registration and electoral campaign). Moreover, although the emergence of such platforms is associated with youth activism (Nuvunga 2018; Tsandzana 2018), we cannot categorically assert that Txeka was used only by young people, given the impossibility of obtaining disaggregated age or gender data from the platform itself. This finding is in line with Fazenda's comments as txekador during the 2014 elections, when interviewed in Maputo on 22 July 2017:

I consider the civil society initiatives as the best way to engage young people, because they are organizations that still have some confidence from young people, such as Txeka. However, these platforms must be increasingly accessible to citizens so that people can say something about electoral processes.

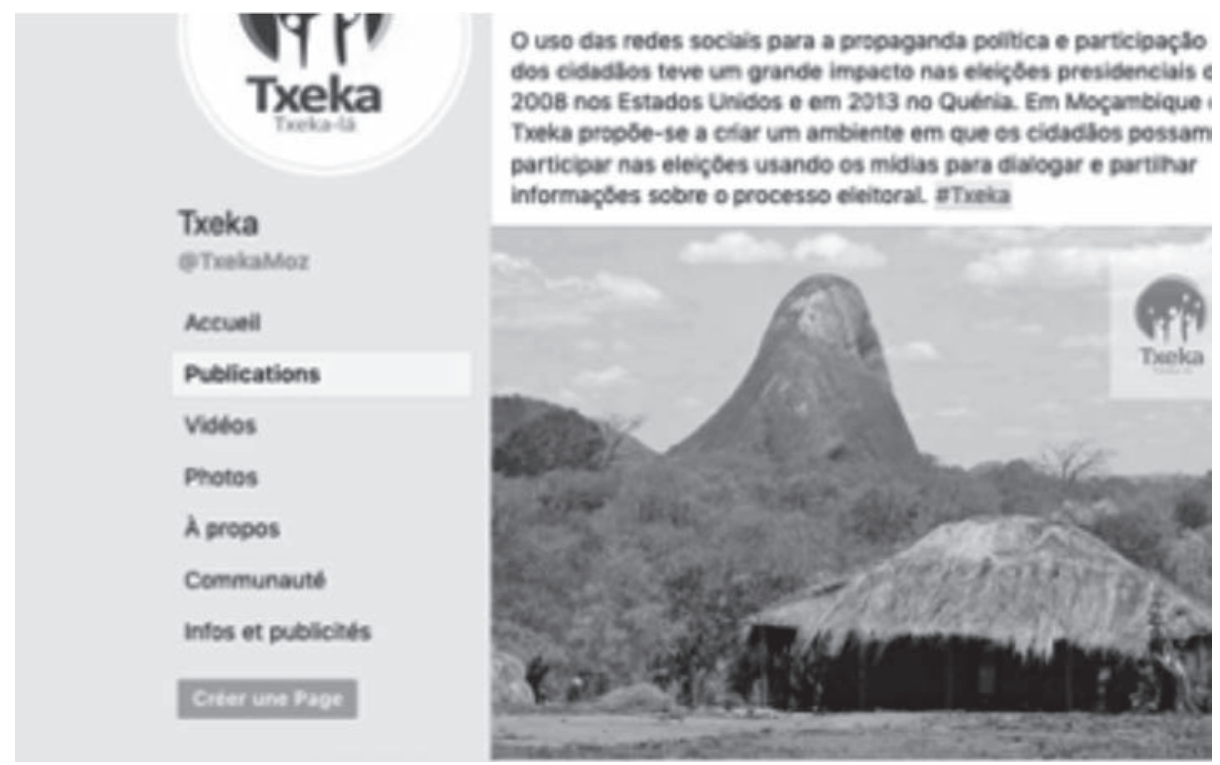

[Screenshot 2: The use of social networks for political propaganda and citizen participation has had a major impact on the 2008 presidential elections in the United States and in 2013 in Kenya. In Mozambique, Txeka proposes to create an environment in which citizens can participate in elections by using the media to dialogue and share information about the electoral process. \#Txeka I 22 September 2014] 


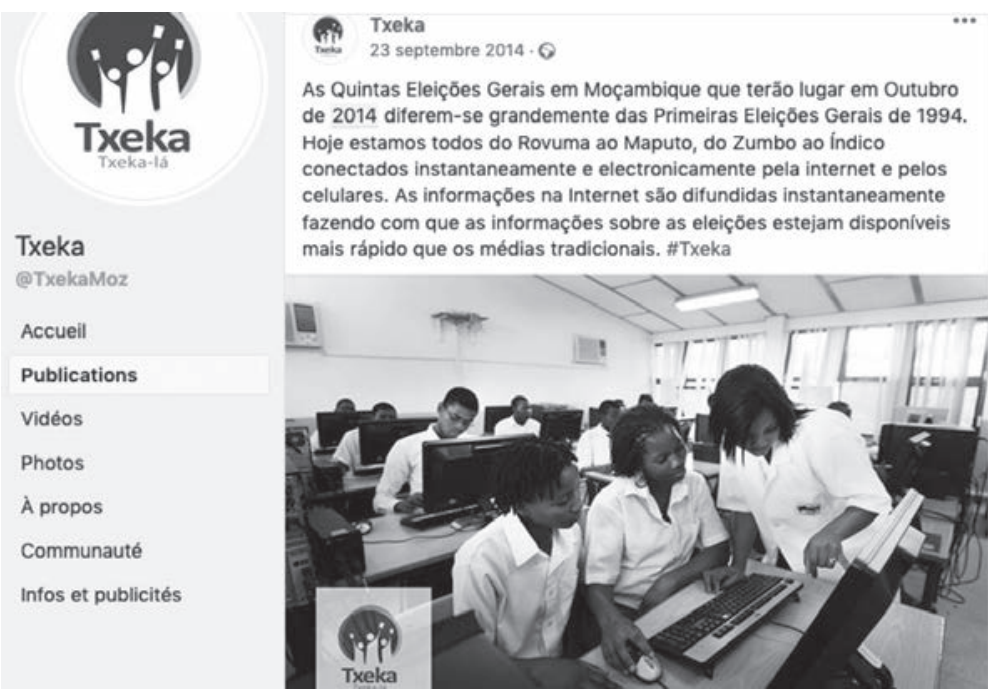

[Screenshot 3: The Fifth General Elections in Mozambique that will take place in October 2014 differ absolutely from the First General Elections of 1994. Today we are all from Rovuma to Maputo, from Zumbo to the Indian Ocean connected instantly and electronically over the internet and cell phones. Information on the Internet is disseminated instantly, making election information available faster than traditional media | 23 September 2014]

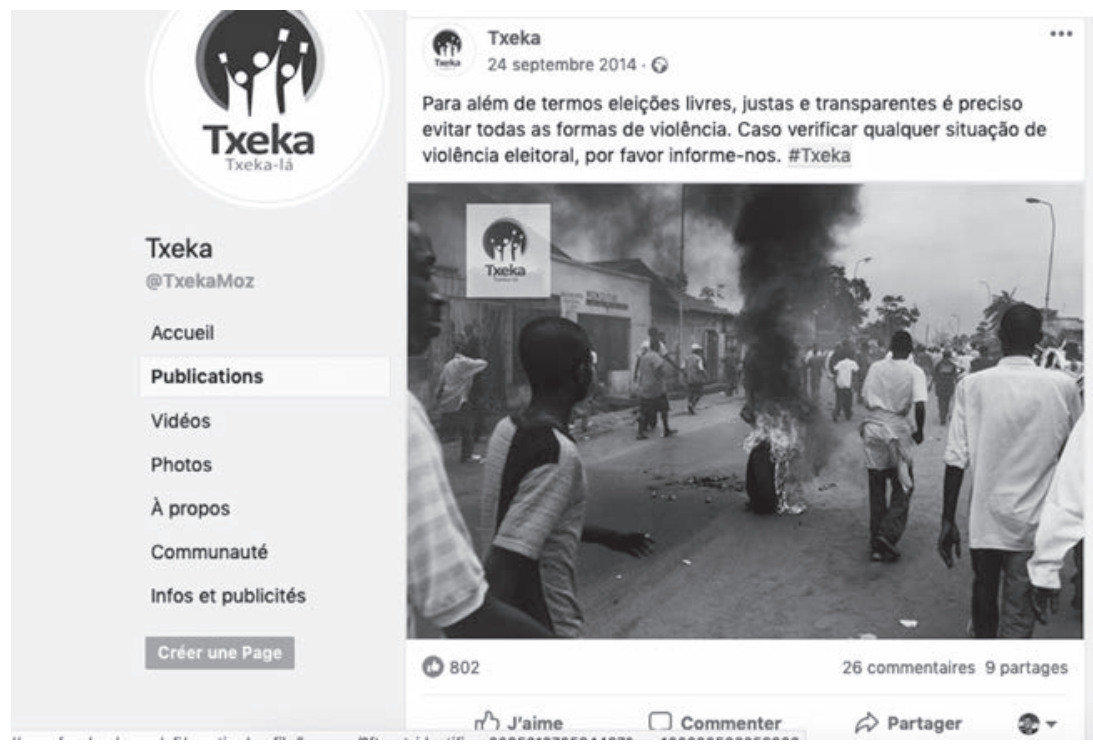

[Screenshot 4: In addition to free, fair and transparent elections, all forms of violence must be avoided. If you check any situation of electoral violence, please let us know. \#Txeka I 24 September 2014] 


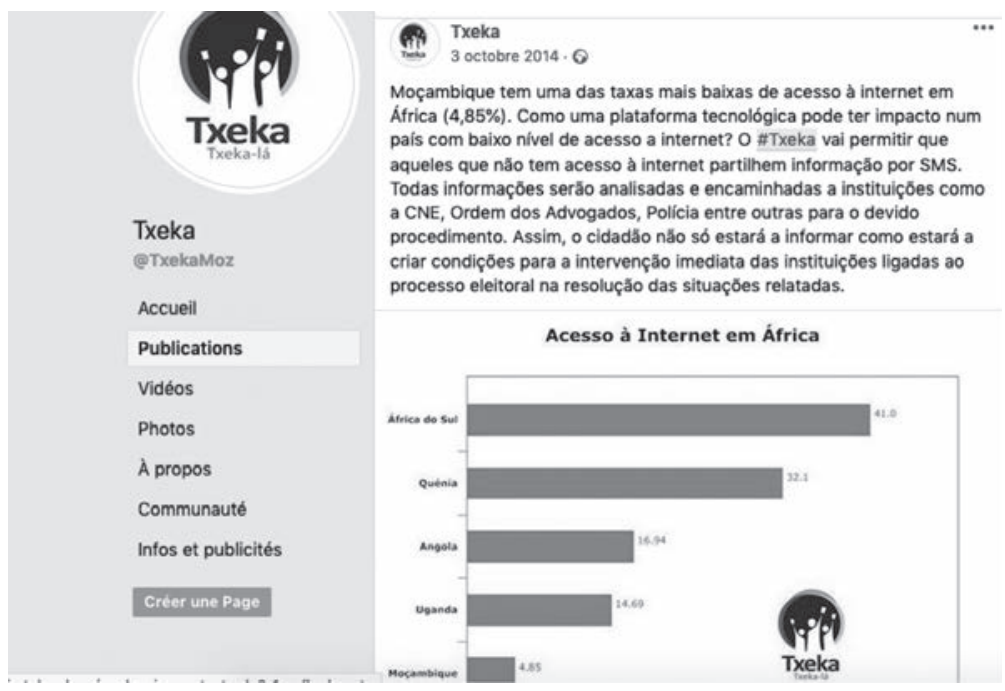

[Screenshot 5: Mozambique has one of the lowest rates in terms of access to the Internet access in Africa $(4.85 \%)^{13}$. How can technology platforms bring about impact on a country with low internet access? \# Txek a will allow those who do not have internet access to share information via SMS. All information will be analysed and forwarded to institutions such as the CNE, Order of Lawyers, Police and others. Thus, the citizens will not be the informants, but will also be creating the conditions for the immediate intervention of the institutions related to the electoral process in the resolution of the reported situations 1 3 October 2014]

13 There is divergent data on Internet access in Mozambique, which is $18 \%$ according to Kemp (2019) and 4.5\% according to the International Telecommunication Union (2018). 
Reacting to the publication, Alexande said that Txeka was a new experience in Mozambique and it could contribute to transparency during the elections:

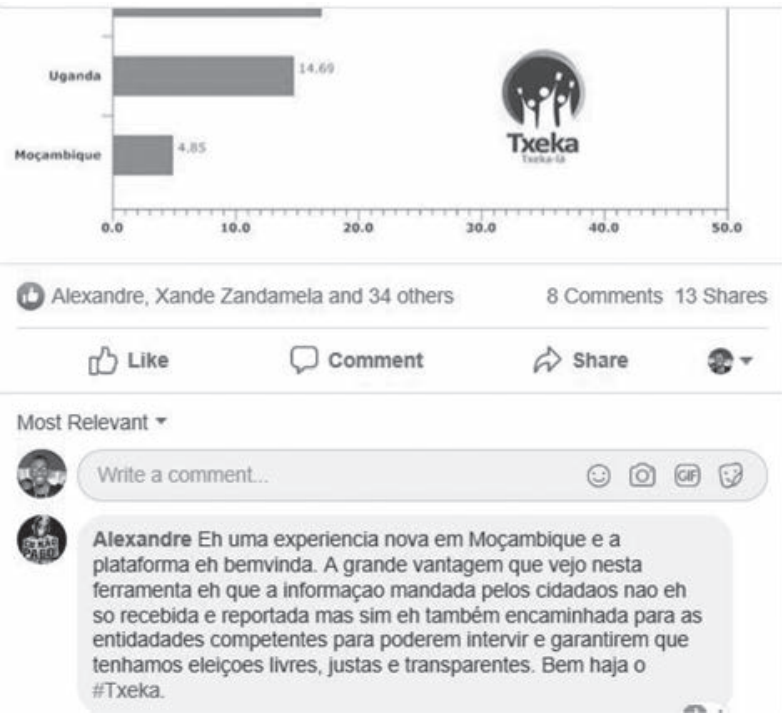

[Screenshot 6: This is a new experience in Mozambique and the platform is welcome. The advantage in this platform is that the information sent by the citizens is not only received and reported but is also forwarded to the relevant authorities to intervene and ensure that we have free, fair and transparent elections I 3 October 2014]

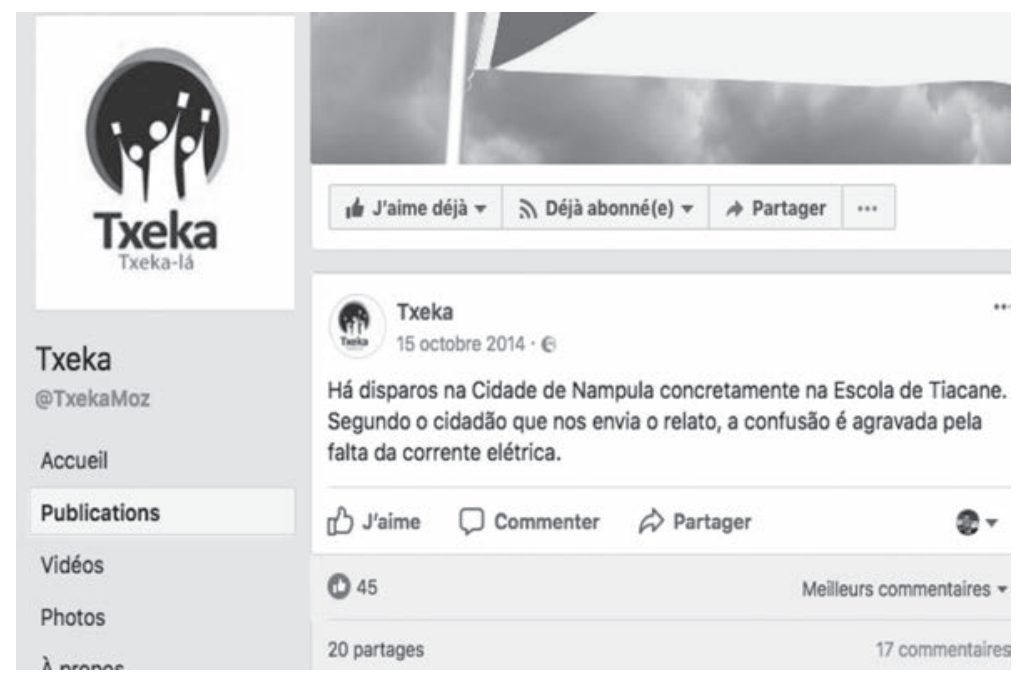

[Screenshot 7: There is shooting in Nampula city, in the school of Tiacane. According to the citizen report, there is no electricity, which hampers the situation I 15 October 2014] 
In this regard two users/followers commented on the publication with different point of views:
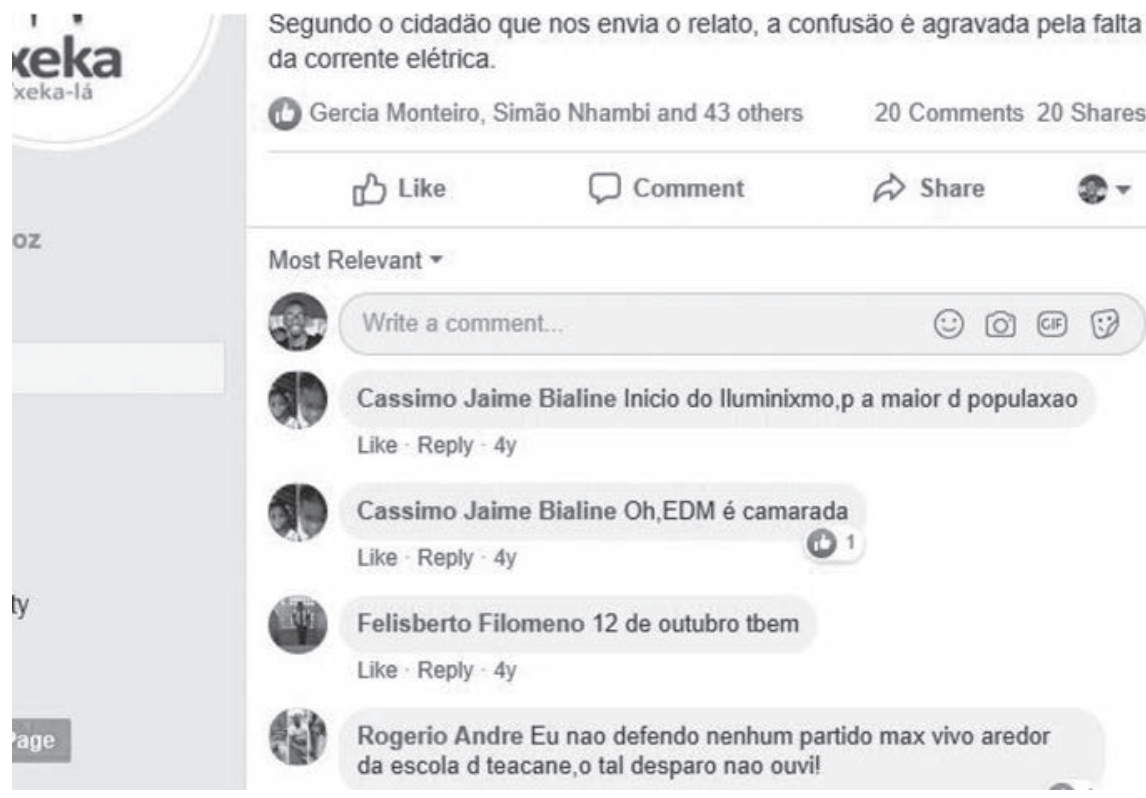

Gercia Monteiro, Simão Nhambi and 43 others

20 Comments 20 Shares

ه Like $\varnothing$ Comment Share

Most Relevant *

Write a comment.

(-) (아 (ㄷ)

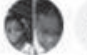

Cassimo Jaime Bialine Inicio do lluminixmo,p a maior d populaxao

Like - Reply - $4 y$

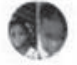

Cassimo Jaime Bialine Oh,EDM é camarada Like - Reply - $4 y$

Felisberto Filomeno 12 de outubro tbem

Like - Reply - $4 y$

Rogerio Andre Eu nao defendo nenhum partido max vivo aredor da escola d teacane,o tal desparo nao ouvi!

[Screenshot 8: Cassimo Jaime -It's the beginning of the enlightenment for the majority of population. The electricity of Mozambique is camarada ${ }^{14}$. I

Rogerio Andre - I don't support any parties, but I live near the school, and I didn't hear any shot. I 15 October 2014]

These publications indicate that Txeka can be considered as empowering people to become sources of information, which O'Reilly (2007, p. 24) summarised as 'the power of social media to (1) create and (2) access self-generated contents'. At the same time, social media facilitate the proliferation of information through channels that are becoming both easier to use and more accessible. Txeka can also be viewed as 'a platform for political discourse' (Nguyen 2011), which reflects the increasingly interactive nature of the web where people can not only receive but also add information. The web has thus become scalable in the sense that people can personalise the type of information they wish to receive and they can also disseminate their own information amongst other people in their social network. The emergence of Txeka thus appears to signal a change in the practice of electoral observation and monitoring in Mozambique, which in previous elections was anchored in a model where television and radio were the main channels.

14 Comrade (camarada) is the popular name to refer to members of Frelimo ruling party in Mozambique. 
The process of electoral observation and monitoring conducted by CSOs, among others, is a crucial step in giving credibility to the electoral process to the extent that it is mentioned in the final ruling of the Constitutional Council proclamation on the 2014 electoral results. However, as previously noted regarding the quality of debate, we think that Txeka cannot be generalised as an open space for all. This is mainly due to unequal access to the internet, as well as the fact that this platform failed to maintain any stability beyond the elections. Indeed, political participation as we have seen above is largely anchored in the elections. Thus, various initiatives appear at election times, but as with the election observation and monitoring processes, the focus should be on scrutinising not only the elections, but the electoral process as a whole from the voter registration phase.

Finally, our interviews reveal the need to build own capacity so that Mozambican organisations can create their initiatives. The Txeka platform was anchored on an initiative from Kenya, with limited access to information on how the database was organised, as well as the processing or provenance of the information received and disseminated during the 2014 general elections. Some platform features, particularly those indicating sending region and message quantity, were dominated by Kenyan technicians and after 2014 this platform did not have the same impact and continuity.

\section{CONCLUSION}

Electoral observation and monitoring platform Txeka is a digital communication initiative, and a counterpublic activism movement (Dahlberg 2007) made by young enthusiasts through information and communication technologies (ICT) to monitor public and government activities using on-line platforms.

It can be considered as an 'election watchdog'15 (Norris \& Nai 2017, p. 3). Txeka was arguably the first empirical experience in challenging the long history of electoral observation made by traditional media (radio and television) in Mozambique. This result seems to be consistent with other research which has found that in recent years, electoral observation missions have been turning to ICT for the timely collection of data and easy processing. This in turn allows electoral management bodies to quickly identify problems and take actions to resolve them (Matsimbe 2019).

15 To supplement the conventional chain of electoral accountability in democratic states it is important to involve multiple channels; upwards towards the international community, horizontally among state agencies, and vertically downwards to civil society. These safeguards are designed to strengthen mechanisms of transparency, accountability, and compliance. 
With regard to ethical implications underpinning the 'big data' phenomenon, this article concludes that there are four basic questions when undertaking research on social media tools. These are:

- how to guarantee the sustainability of these platforms

- what is the status of so-called 'public' data on social media sites

- can it simply be used, without requesting permission

- what constitutes best ethical practice for researchers.

Democracy has at its heart self-determination, participation, voice and autonomy. Through initiatives such as Txeka, democracy can mean much more than simply voting or providing better public information to the citizens.

\section{Acknowledgements}

I wish to thank Leonilda Sanveca (PhD, Maputo Pedagogic University) for helping me to prepare this communication. I am also deeply grateful to the laboratory Les Afriques dans le Monde/Sciences Po Bordeaux (France) for the support to participate in ECAS, as well as the IFAS-Research (Johannesburg) and the AFRAMO-CHS (Maputo) for financing my fieldwork-research in Mozambique. Finally, I want to thank Laüra Hoskins (Bordeaux University), Ricardo Mujui and Lissungu Mazula for helping me to correct and review this manuscript and improve my English.

A4AI [Alliance for Affordable Internet] 2019, Measurement matters: why looking at income is crucial to internet affordability, World Wide Web Foundation, Geneva. ABC/AFP News 2014, Namibian election first in Africa to use electronic voting machines. Available at $<$ hwww.abc.net.au/news/2014-11-28/namibian-election-first-in-africa-to-use-electronic-voting/5927206 > [24 July 2019]

Adebisi, A \& Loremikan, S 2013, 'Election Observation in Nigeria: Prop or Threat to Democratic Consolidation?', Canadian Social Science, vol. 9, no. 6, pp. 140-146.

Beaufort, M 2018, Digital media, political polarization and challenges to democracy', Information, Communication \& Society, vol. 21, no. 7.

Bimber, B \& Flanagin, A 2005, 'Reconceptualizing collective action in the contemporary media environment', Communication Theory, vol. 15, pp. 365-388.

Boyd, D. \& Ellison, N 2008, 'Social Network Sites: Definition, History, and 
Scholarship', Journal of Computer-Mediated Communication, vol 3, no. 1, pp. 210-230.

Branch, A \& Mampilly, Z 2015, Africa uprising: popular protest and political change, ZED Books, London.

Bruijn, ME de 2019, Digitalization and the field of African studies, Basler Afrika Bibliographien, Basel.

Calderaro, A 2018, Social Media and Politics, SAGE Handbook of Political Sociology, London.

Castells, M 2001, La galaxie internet, Fayard, Paris.

Dahlberg, L 2007, 'The Internet, deliberative democracy, and power: radicalising the public sphere', International Journal of Media and Cultural Politics, vol. 3, no. 1, pp. 47-64.

Dahlberg, L 2011, 'Re-constructing digital democracy: An outline of four positions', New media \& society, vol. 13, no. 6, pp. 855-872.

Dahlberg, L 2015, 'Expanding digital divides research: a critical political economy of social media', The Communication Review, vol. 18, pp. 271-293.

De Boeck, F \& Honwana, A 2005, Makers and Breakers: Children and Youth in Postcolonial Africa, Africa World Press, Trenton, NJ.

Devermont, J 2019, The internet is changing Africa, CNET [USA].

Dimitrova, D \& Shehata, A2014, 'The effects of digital media on political knowledge and participation in election campaigns', Communication Research, vol. 41, no. 1.

Dodsworth, S \& Cheeseman, N 2019, 'The technological transformation of elections and election observation: Africa in comparative perspective', ECAS, Edinburgh.

Dwyer, M \& Molony, T 2019, Social media and politics in Africa: democracy, censorship and security, ZED Books, London.

Dzisah, WS 2008, 'Social media and elections in Ghana: enhancing democratic participation', African Journalism Studies, vol. 39, no.1.

Electoral law 2018, Election of local authorities, no. 6/2018.

Electoral law 2018, Election of local government, no. 7/2018.

Farrell, H \& Drezner, D 2004, The power and politics of blogs, Colloquium American Political Science Association.

Fisher, DR \& Waggle, J 2013, 'Where does political polarization come from? Locating polarization within the U.S. climate change debate', American Behavioral Scientist, vol. 157, no.1.

Foot, K \& Schneider, M 2006, Web campaigning, MIT Press, Cambridge, Mass. Frantz, E 2016, Autocracy, Oxford Research Encyclopedia of Politics, [Oxford]. Freyburg, T 2018, 'Internet Shutdowns and Ownership at Election Times in SubSaharan Africa', International Journal of Communication, vol.12, pp. 38963916. 
Gwagwa ,A 2016, Manifestation of realpolitik in cyberspace: Analysis of the relationship between internet-based information controls and Elections in Zambia, CIPESA, Kampala.

Hine, C 2000, Virtual ethnography, SAGE, London.

Honwana, A 2014, The Time of Youth: Work, Social Change, and Politics in Africa, Kumarian Press, Sterling VA.

Huet, J-M 2017, Le digital en Afrique - Les cinq sauts numériques, Michel Lafon, Paris. Ifukor, P 2010, 'Elections" or "Selections"? Blogging and twittering the Nigerian 2007 general elections', Bulletin of Science, Technology \& Society, vol. 30, no.6, pp. 398-414.

Kaur-Gill, S \& Dutta, M 2017, 'Digital ethnography', The International Encyclopedia of Communication Research Methods, vol. 10, no. 1.

Kemp, S 2019, Digital 2019: Mozambique, Hootsuite, Vancouver.

Lee RA, Verba, S 2012, Social Media and Political Engagement, Pew Research Center, Washington, DC.

Leeffers, S 2017, Does Electoral Observation Influence Electoral Results? Experimental Evidence for Domestic and International Observers in Mozambique, NOVAFRICA, Lisbon.

Leistert, O 2013, 'Smell the fish: Digital Disneyland and the right to oblivion', First Monday, vol.18, no. 3-4.

Lyons, T 2004, 'Post-conflict Elections and the Process of Demilitarizing Politics: The Role of Electoral Administration', Democratization, vol. 11, no. 3, pp. 36-62.

Marcus, G 1998, 'Ethnography in/ of the World System: The Emergence of MultiSited Ethnography', Annual Review of Anthropology, vol. 24, pp. 95-117.

Mare, A 2015, Facebook, youth and political action: a comparative study of Zimbabwe and South Africa, Thesis (PhD), Rhodes University.

Margolis, M \& Resnick, D 2000, Politics as usual: the cyberspace 'revolution', Sage, Thousand Oaks CA.

Markham, A 2006, 'Ethic as method, method as ethic', Journal of Information Ethics, vol. 15 no. 2, pp. 37-54.

Matos, H 2008, 'Engagement civique et participation politique: controverses sur les TICs et le déclin du capital social', Les Enjeux de l'information et de la communication, vol. 1, pp. 57-71.

Matsimbe, Z 2019, 'Electoral Observation: A mechanism to support the strengthening of democracy and credibility of the country', Journal of African Elections, vol 18, no. 1.

Molony, T \& Macdonald, R 2019, Re-evaluating international observation of Kenya's 2017 elections, ECAS, Edinburgh.

Mudhai, O 2013, Civic engagement, digital networks, and political reform in Africa, Palgrave Macmillan, New York. 
Muxel, A 2016, Temps et politique: Les recompositions de l'identité, Presses de Sciences Po, Paris.

Ndavula, J \& Mueni, J 2014, 'New media and political marketing in Kenya: The case of 2013 general elections', International Journal of Arts and Commerce, vol. 3, no. 6, pp. 69-84.

Nelimarkka, M 2018, 'Social Media Is Polarized, Social Media Is Polarized: Towards a New Design Agenda for Mitigating Polarization', Designing Interactive Systems DIS, vol. 13, no. 9, pp. 957-970.

Nguyen, T 2011, 'Twitter: a Platform for Political Discourse or Social Networking', Global Tides, vol. 5, no. 11.

Norris, P \& Nai, A 2017, Election Watchdogs: Transparency, Accountability and Integrity, Oxford University Press, Oxford.

Nuvunga, A 2018, A participação da juventude num contexto onde o activismo tem estado a diminuir: o caso de Moçambique, AGIR OXFAM, Maputo.

Nyabola, N 2019, Digital democracy, analogue politics: how the Internet era is transforming Politics in Kenya, ZED Books, London.

O'Reilly, T 2007, 'What is the Web 2.0? Design patterns and business models for the next generation of software', Communications and strategies, vol. 65 , no. 2 .

Pereira, MA 2011, 'Internet e mobilização política - os movimentos sociais na era digital'. In Anais do IV Encontro da Associação Brasileira de Pesquisadores em Comunicação e Política.

Richaud, C 2018, 'Les réseaux sociaux : nouveaux espaces de contestation et de reconstruction de la politique'. In Sales. E (dir), Le numérique au service du renouvellement de la vie politique, pp. 69-75, LGDJ, Paris.

Salgado, S 2016, The Internet and democracy building in Lusophone African countries, Routledge, London.

Schroeder, R 2018, Social Theory after the Internet: The internet in theory, UCL Press, London.

Statista portal, Number of mobile cellular subscriptions per 100 inhabitants in Mozambique from 2000 to 2017. Available at < https:/ / www.statista.com > [10 July 2019]

Stromer-Galley, J 2003, 'Diversity of political conversation on the Internet: users' perspectives', Computer mediated communication, vol. 8, no. 3 .

Teorell, J \& Mariano, T 2007, Political participation: Mapping the terrain, Routledge, London.

Tsandzana, D 2018, 'Juventude urbana e redes sociais em Moçambique: a participação política dos conectados desamparados', Sociedade $e$ Comunicação, vol. 34, no. 2.

Van Dijk, JAGM 2012, 'The evolution of the digital divide: The digital divide turns to inequality of skills and usage', In J Bus, M Crompton, M Hildebrandt, \& G Metakides (Eds.), Digital enlightenment yearbook, IOS Press, Amsterdam. 